\title{
ANTARA SEJARAH DAN SASTRA: NOVEL SEJARAH SE- BAGAI BAHAN AJAR PEMBELAJARAN SEJARAH
}

\author{
Ramilury Kurniawan \\ Pascasarjana Pendidikan Sejarah, Universitas Negeri Malang
}

\begin{abstract}
Abstrak: Pelajaran sejarah identik dengan pelajaran yang membosankan dan kurang menarik. Oleh karena itu, praktisi pendidikan pelajaran sejarah terus berinovasi mengembangkan bahan ajar yang menarik. Sayangnya, pengembangan bahan ajar pelajaran sejarah yang selama ini dilakukan kurang memperhatikan budaya literasi bagi peserta didik. Dampaknya adalah kegiatan membaca buku bagi peserta didik menjadi berkurang. Padahal pada pelajaran sejarah, membaca adalah kegiatan yang penting untuk memperluas wawasan dan pemahaman peristiwa sejarah. Di sisi lain, buku yang tersedia di sekolah mayoritas merupakan buku paket dan LKS. Buku paket dan LKS ditulis dengan menggunakan bahasa ilmiah yang akan membuat peserta didik mudah bosan. Oleh karena itu, dibutuhkan pemanfaatan bahan bacaan pelengkap untuk peserta didik. Bahan bacaan pelengkap yang bisa dimanfaatkan adalah novel sejarah. Novel sejarah dapat dijadikan bahan bacaan pelengkap bagi peserta didik dan sebagai bahan ajar dalam pelajaran sejarah. Kelebihan novel sejarah adalah bahasa dan cerita yang ada didalamnya lebih menarik namun tetap tidak meninggalkan latar belakang sejarah. Kekurangan novel sejarah adalah terdapat unsur subyektifitas pengarang dan kurangnya novel sejarah yang sesuai dengan materi yang dibahas dalam pelajaran sejarah. Melihat penjelasan tersebut guru sejarah harus selektif dalam memilih novel sejarah yang akan digunakan dalam pelajaran sejarah. Dengan menggunakan novel sejarah diharapkan peserta didik memiliki budaya literasi sekaligus menambah wawasannya dalam memahami sebuah peristiwa sejarah.
\end{abstract}

Kata-kata Kunci : bahan ajar, novel, novel sejarah, pembelajaran sejarah

Abstract: History learning is identified as a boring and unattractive subject. Thereby, history educators keep emerging innovation to develop exciting learning media. Unfortunately, learning media improvement does not really notice students' literacy culture. This affects reading books behavior of students becomes decreased. Whereas, regarding history, reading is an essential action in term to broaden the horizon and intensify the understandings of history events. In the other side, provided books in the school are textbook and worksheet. These textbooks and worksheets were arranged using scientific terms which bring students easily tired. Thus, it requires an addition reading source for students. Additional reading materials that may be used is historical novel. The historical novel can be developed as a supplementary source and learning media regarding history learning. The advantages of history novel are language simplicity used and appealing stories that still exposing history background. The drawbacks of history novel utilization are authors' subjectivity content and the deficient number of history novel that associated to substances that being studied of history learning. Based on the description above, history should be selective in taking a historical novel that will be utilized in history learning. By using historical novel is expected that students may gain literacy culture in line with increasing their insight when try to understand about history events.

Keywords: learning media, novel, historical novel, history learning

Mata pelajaran sejarah merupakan salah satu mata pelajaran yang penting dalam dunia pendidikan di Indonesia. Menurut Aman (2011:57) mata pelajaran sejarah 
memiliki arti yang strategis dalam pembentukan watak dan peradaban bangsa yang bermartabat serta dalam pembentukan manusia Indonesia yang memiliki rasa kebangsaan dan cinta terhadap tanah air. Menurut Notosutanto (1979: 10) bahkan dari 8 rancangan penting dalam pembangunan nasional, 5 di antaranya adalah produk sejarah. Pendapat ini memberikan gambaran kepada kita betapa pentingnya pelajaran sejarah.

Mata pelajaran sejarah mencakup materi mengenai sejarah Indonesia dan dunia. Menurut Agung \& Wahyuni (2013: 55-57) sejarah adalah mata pelajaran yang menanamkan pegetahuan, sikap, dan nilainilai mengenai proses perubahan dan perkembangan masyarakat Indonesia dan dunia di masa lampau hingga masa kini. Pendapat lain dikemukakan oleh Joebagio (dalam Garvey, dkk, 2015: xi) yang mengemukakan bahwa pembelajaran sejarah adalah proses internalisasi nilai-nilai peristiwa masa lalu, berupa asal-usul, silsilah, pengalaman kolektif, dan keteladanan pelaku sejarah. Dari dua pendapat di atas dapat disimpulkan bahwa pelajaran sejarah merupakan pelajaran mengenai masa lalu yang dapat diambil hikmah dan nilainya bagi kehidupan manusia.

Penjelasan di atas memberikan gambaran kepada kita betapa pentingnya pelajaran sejarah bagi peserta didik. Namun, pada kenyataannya, pelajaran sejarah identik dengan pelajaran yang membosankan dan kurang diminati. Menurut Widja (2012: 76) pelajaran sejarah selama ini kurang diminati oleh peserta didik. Hal ini dikarenakan pelajaran sejarah diidentikkan dengan pelajaran yang harus menghafal peristiwa, tokoh, dan tahun-tahun. Pelajaran sejarah juga dianggap tidak penting untuk dipelajari karena terjadi di masa lampau dan tidak ada hubungannya dengan masa yang akan datang.

Sebenarnya masalah-masalah pembelajaran sejarah yang membosankan dan kurang menarik bagi peserta didik sudah terjadi sejak dulu. Hill (1956: 9-19) menuliskan bahwa masalah-masalah pembelajaran yang tidak menarik dan membosankan sudah ada sejak dia menulis buku tersebut, artinya pada masa 1950-an. Dalam bukunya tersebut, Hill juga menawarkan metodemetode yang dapat dipertimbangan dalam mengajar sejarah. Dari tulisan tersebut kita bisa mengetahui bahwa sebenarnya upaya menyelesaikan masalah pembelajaran sejarah agar lebih menarik sudah ada sejak dulu.

Pada hakikatnya, pelajaran sejarah bukan hanya pelajaran yang menghafalkan tokoh, tahun, dan tempat. Sebaliknya, sejarah selalu berhubungan dengan menafsirkan, memahami, dan mengerti (Kuntowijoyo, 2008: 2). Nilai terpenting dari pembelajaran sejarah tersebut adalah ketrampilan pemahaman sejarah yang dapat diterapkan oleh peserta didik, baik dalam kehidupan sehari-hari maupun dalam bidang lain seperti sosial, budaya, dan politik.

Fakta di lapangan menunjukkan bahwa untuk dapat menafsirkan, memahami, dan mengerti sejarah, guru sejarah lebih banyak menggunakan buku paket dan LKS sebagai sumber. Bahasa yang digunakan dalam buku paket dan LKS ini merupakan bahasa ilmiah yang cenderung akan membuat peserta didik mudah bosan. Buku paket dan LKS yang diberikan kepada peserta didik berisi fakta-fakta peristiwa sejarah sejak masa prasejarah hingga peristiwa kontemporer yang disajikan dengan singkat dan padat. Buku paket dan LKS seolah memaksa peserta didik untuk menghafalkan semua materi yang ada didalamnya. Akibatnya, selain membosankan, juga akan mengurangi minat baca peserta didik.

Salah satu solusi yang bisa ditawarkan untuk mengatasi masalah ini adalah dengan memberikan buku bacaan lainnya kepada peserta didik. Buku bacaan dengan 
bahasa yang mudah dipahami dan memuat unsur sastra akan lebih menarik kepada peserta didik. Buku bacaan seperti ini terdapat pada novel. Novel yang dimaksud disini tentunya adalah novel sejarah yang memuat materi sesuai dengan kurikulum pembelajaran sejarah. Novel sejarah akan lebih mudah dimengerti daripada sejarah nonfiksi yang ilmiah karena bahasa yang digunakan lebih mudah dalam dipahami (Howell, 2014:4).

Artikel ini akan membahas mengenai pemanfaatan novel sejarah dalam pembelajaran. Sebelum membahas pemanfaatan novel sejarah dalam pembelajaran, tentunya akan dibahas terlebih dahulu mengenai apa yang dimaksud dengan novel dan novel sejarah. Novel sejarah dianggap mampu dijadikan sebagai bahan bacaan alternatif dikarenakan dalam novel sejarah tersebut terdapat unsur materi sejarah. Bahan bacaan dalam bentuk novel juga akan menarik minat baca peserta didik. Berdasarkan pengamatan penulis selama menjadi guru di SMA Darul Ulum 1 Jombang, peserta didik lebih berminat membaca novel daripada buku paket dan LKS. Hal inilah yang melatarbelakangi penulis untuk mengawinkan unsur sastra yang ada dalam novel dan unsur materi sejarah. Peserta didik diharapkan akan lebih mudah memahami materi sejarah sekaligus mengembangkan imajinasinya dalam sebuah karya sastra dengan membaca novel sejarah. Permasalah yang akan dibahas dalam artikel ini meliputi: (1) apa yang dimaksud dengan novel sejarah?, (2) bagaimana novel sejarah bisa menjadi salah satu bahan ajar pelajaran sejarah?, dan (3) bagaimana penggunaan novel sejarah dalam kegiatan pembelajaran sejarah?

\section{BAHAN AJAR DALAM PEMBELA- JARAN SEJARAH}

Pemanfaatan bahan ajar dalam pembelajaran sejarah sangatlah penting. Pembelajaran sejarah akan lebih menarik bagi peserta didik dengan adanya bahan ajar. Saat ini, pemanfaatan bahan ajar dalam pembelajaran sejarah sudah banyak dilakukan. Guru sejarah sudah tidak lagi terpaku pada metode ceramah dengan menggunakan media papan tulis saja. Beragam jenis bahan ajar sudah digunakan dalam pembelajaran sejarah.

Beberapa penelitian yang telah dilakukan menghasilkan pemanfaatan dan pengembangan bahan ajar dalam pembelajaran sejarah. Pemanfaatan dan pengembangan bahan ajar tersebut memiliki pengaruh terhadap pembelajaran. Sebagai contoh adalah penelitian yang dilakukan oleh Nurhayati (2016) yang mengembangkan multimedia interaktif muatan IPS berbasis inquiri pada siswa kelas V. Penelitian kedua adalah dari Ariffiantono (2011) yang mengembangkan pembelajaran berbasis e-learning dengan aplikasi Moodle sejarah Eropa pada siswa SMA kelas XI di SMAN 10 Malang. Penelitian ketiga dihasilkan oleh Ramadloni (2016) yang menulis mengenai pengembangan bahan ajar digital sejarah nasional Indonesia berbasis kakawin Negarakretagama untuk meningkatkan kemampuan eksplanasi sejarah mahasiswa program studi sejarah FKIP Universitas Jember. Ketiga penelitian itu menghasilkan produk yang dapat digunakan dan dipertanggung jawabkan kevalidannya dalam pembelajaran sejarah bagi peserta didik.

Dari beberapa penelitian yang telah disebutkan di atas tentu merupakan hal yang sangat bermanfaat sekali dalam pembelajaran sejarah. Namun, jika kita analisis kembali, pengembangan dan pemanfaatan bahan ajar sejarah selama ini kurang memperhatikan hal penting dari pembelajaran sejarah, yaitu membaca buku. Padahal kegiatan membaca tidak bisa dilepaskan dari pelajaran sejarah. Membaca buku akan memperluas wawasan dan pemahaman peserta didik terhadap peristiwa sejarah. 
Masalah kemudian muncul ketika bahan ajar buku yang terdapat di sekolah kurang menarik minat baca siswa. Buku paket, LKS, dan modul yang digunakan selama ini menggunakan bahasa ilmiah yang mudah membuat siswa bosan. Oleh karena itu, diperlukan bahan bacaan yang dapat menarik minat baca peserta didik. Bahan ajar novel sejarah merupakan salah satu alternatif bahan bacaan yang dapat diberikan kepada peserta didik. Hal ini dikarenakan bahasa yang digunakan dalam novel sejarah lebih menarik dan mudah dipahami daripada bahasa yang digunakan pada buku paket, LKS, maupun modul.

Bahan ajar adalah seperangkat sarana atau alat pembelajaran yang berisikan materi pembelajaran, metode, batasan-batasan, dan cara mengevaluasi yang didesain secara sistematis dan menarik dalam rangka mencapai tujuan yang diharapkan, yaitu mencapai kompetensi atau subkompetensi dengan segala kompleksitasnya (Widodo dan Jasmadi dalam Lestari, 2013: 1). Dari penjelasan tersebut bisa dikatakan bahwa bahan ajar merupakan segala alat pembelajaran yang bisa digunakan untuk mencapai tujuan pembelajaran. Bahan ajar dirancang atau disusun oleh seorang guru sesuai dengan tujuan kompetensi yang diharapkan kepada peserta didiknya. Peran seorang guru dalam merancang ataupun menyusun bahan ajar sangatlah menentukan keberhasilan proses belajar dan pembelajaran melalui sebuah bahan ajar. Bahan ajar dapat juga diartikan sebagai segala bentuk bahan yang disusun secara sistematis yang memungkinkan peserta didik dapat belajar secara mandiri dan dirancang sesuai kurikulum yang berlaku. Guru akan lebih mudah dalam mengajarkan materi kepada peserta didik dengan adanya bahan ajar.

Bahan ajar memiliki beragam jenis, ada yang cetak maupun noncetak. Bahan ajar cetak dapat berupa handout, buku, modul, brosur, dan lembar kerja siswa. Khusus untuk bahan ajar berupa buku dapat dibedakan menjadi empat jenis (Prastowo dalam Lestari, 2011: 79) yaitu sebagai berikut : (1) Buku sumber, yaitu buku yang dapat dijadikan rujukan, referensi, dan sumber untuk kajian ilmu tertentu, biasanya berisi suatu kajian ilmu yang lengkap, (2) Buku bacaan, yaitu buku yang hanya berfungsi untuk bahan bacaan saja, misalnya cerita, legenda, novel, dan lain sebagainya, (3) Buku pegangan, yaitu buku yang bisa dijadikan pegangan guru atau pengajar dalam melaksanakan proses pengajaran, dan (4) Buku ajar atau buku teks, yaitu buku yang disusun untuk proses pembelajaran dan berisi bahan-bahan atau materi pembelajaran yang akan diajarkan.

Bahan ajar noncetak meliputi bahan ajar dengar (audio) seperti kaset, radio, piringan hitam, dan compact disc audio. Bahan ajar pandang dengar (audio visual) seperti video compact disc dan film. Bahan ajar multimedia interaktif (interactive teaching material) seperti CIA (Computer Assisted Intruction), compact disc (CD) multimedia pembelajaran interaktif, dan bahan ajar berbasis web (web based learning materials) (Lestari, 2013: 6).

Penjelasan mengenai bahan ajar di atas membuka peluang untuk pemanfaatan bahan ajar yang dapat meningkatkan budaya membaca sekaligus meningkatkan pemahaman peserta didik terhadap peristiwa sejarah. Bahan ajar novel sejarah dapat dilakukan untuk mencapai tujuan tersebut. Novel sejarah merupakan bahan ajar yang termasuk sebagai bahan ajar buku yaitu buku bacaan. Novel sejarah memang banyak kita temukan di toko-toko buku, namun belum tentu semuanya sesuai dengan pembelajaran sejarah. Oleh karena itu guru harus selektif dalam memilih novel sejarah sesuai dengan kebutuhan kompetensi yang akan dicapai oleh peserta didik. Seorang 
guru sejarah juga bisa melengkapi novel sejarah tersebut dengan panduan penggunaan sekaligus evaluasi pembelajaran agar dapat menjadi sebuah bahan ajar.

Guru sejarah dapat menggunakan novel sejarah sebagai bahan ajar dengan menggunakan metode-metode yang sesuai dengan tujuan kompetensi yang akan dicapai. Sebagai contoh, guru dapat memberikan tugas membaca novel sejarah seminggu sebelum pelajaran dimulai. Pada saat pelajaran dimulai, guru sejarah bisa menggunakan metode debat. Guru memberikan pancingan topik-topik yang menarik dalam novel agar peserta didik mengeluarkan pendapatnya. Selain metode debat, metode-metode lainnya masih bisa dikombinasikan dengan bahan ajar novel sejarah.

\section{NOVEL SEBAGAI KARYA SASTRA}

Dalam dunia sastra, kita mengenal karya sastra berupa novel dan cerita pendek. Menurut Nurgiyantoro (2000: 9) novel dan cerita pendek merupakan dua karya sastra yang sekaligus disebut sebagai fiksi. Pada perkembangannya, bahkan antara novel dengan fiksi dianggap bersinonim. Hal ini bisa kita lihat dari karya fiksi seperti halnya dalam kesastraan Inggris dan Amerika. Di kesastraan Inggris dan Amerika, karya fiksi menunjuk pada novel dan cerita pendek. Dengan demikian, dapat ditarik kesimpulan bahwa pengertian fiksi dan novel adalah hal yang sama.

Menurut Pujiharto (2010: 4) karya fiksi dalam bahasa Indonesia merupakan terjemahan dari kata Inggris, fiction. Kata fiction dalam bahasa Inggris merupakan serapan dari bahasa latin yaitu fictio. Kata fictio sendiri berasal dari kata kerja fingere, fictum. Dalam pengertian yang diambil dari asal-usul kata tersebut, Pujiharto mengatakan bahwa kata fiksi adalah karya yang ditulis dalam bentuk prosa. Prosa sendiri bisa berbentuk novel atau cerita pendek. Menurut Aminudin (2004) prosa adalah kisahan atau cerita yang diemban oleh pelakupelaku tertentu dengan pemeranan latar serta tahap dan rangkaiaan cerita tertentu yang bertolak dari hasil imajinasi pengarangnya sehingga mejalin suatu cerita. Definisi kata fiksi juga terdapat dalam $\mathrm{Ka}$ mus Besar Bahasa Indonesia (KBBI) (1995: 316). Menurut KBBI, fiksi memiliki arti: 1) cerita rekaan (roman, novel, dsb.), 2) rekaan, khayalan, dan tidak berdasar pada kenyataan, 3) pernyataan yang hanya berdasarkan pada khayalan atau pikiran.

Pendapat di atas juga sejalan dengan pendapat dari Nurgiyantoro. Menurut Nurgiyantoro (2000: 2-9) fiksi merupakan cerita rekaan yang dibuat oleh pengarangnya. Karya fiksi dengan demikian menyaratkan kepada suatu karya yang menceritakan sesuatu yang bersifat rekaan, khayalan, sesuatu yang tidak ada dan terjadi sungguh-sungguh sehingga tidak perlu dicari kebenarannya. Hal inilah yang membedakan fiksi dengan karya ilmiah. Karya ilmiah harus bisa dipertanggungjawabkan kebenarannya berdasarkan fakta-fakta yang diperoleh. Karya fiksi merupakan karya imajiner yang secara bebas dituangkan dalam bentuk cerita dan tidak bisa dipertanggungjawabkan kebenarannya.

Kebenaran karya fiksi terdapat pada pengarangnya. Seorang pengarang dengan pengarang lainnya belum tentu memiliki pengertian kebenaran yang sama, dalam hal ini kebenaran merupakan sesuatu yang subyektif. Kebenaran yang ada dalam cerita fiksi bahkan bisa saja bertentangan dengan kebenaran hukum-hukum yang ada di dunia nyata. Penjelasan tersebut membuat kita bisa menyimpulkan bahwa fiksi merupakan cerita yang tidak nyata dan tidak bisa dipertanggungjawabkan kebenarannya. Meskipun begitu, pengarang tentu tidak lepas dari kehidupan dunia nyata yang menjadi obyek ceritanya. 
Seperti yang telah dijelaskan di atas bahwa novel dapat juga disebut sebagai fiksi yang termasuk bagian dari prosa. Oleh karena itu, pengertian novel juga merupakan cerita rekaan, cerita khayal yang tidak dapat diper-tanggungjawabkan kebenarannya. Menurut Nurgiyantoro (2000: 4) novel sebagai karya fiksi menawarkan sebuah dunia, dunia yang berisikan model kehidupan yang diidealkan, dunia imajinatif, yang dibangun melalui berbagai unsur interinsiknya seperti peristiwa, plot, tokoh (dan penokohan), latar, sudut pandang, dan lain-lain. Kesemuanya itu tentu saja dibangun dengan dasar imajinatif.

Perbedaan antara novel dan cerita pendek sebagai sebuah karya fiksi dapat kita lihat dari segi panjangnya cerita. Sebuah cerita yang panjangnya hingga ratusan halaman tentu saja tidak bisa kita sebut sebagai cerpen. Cerpen merupakan cerita pendek yang panjang ceritanya terbagi menjadi tiga yaitu short short story yang berkisar 500-an kata, midle short story yang jumlahnya kisaran 1000-an kata dan long short story yang panjangnya bahkan hingga mencapai puluhan ribu kata. Cerpen yang terdiri dari puluhan ribu kata tersebut tentu sangat panjang sebagai sebuah cerpen, namun masih belum bisa disebut sebagai novel, oleh karena itu, cerita yang panjangnya mencapai puluhan ribu kata tersebut bisa dikategorikan sebagai novelet (Nurgiyantoro, 2000:10).

Dari segi panjang cerita, tentu saja novel memiliki cerita yang lebih panjang daripada cerpen. Oleh karena itu, novel dapat mengemukakan sesuatu secara bebas, menyajikan sesuatu yang lebih banyak, lebih rinci, lebih detail, dan lebih banyak melibatkan berbagai permasalahan yang kompleks. Sebuah novel bisa saja terdiri dari 100 halaman saja, namun juga ada novel yang panjangnya hingga mencapai 1000 halaman lebih. Sebagai contoh adalah novel dengan judul Musashi karya Eiji Yoshikawa (2012) yang mengajak kita kembali ke masa abad ke-16 di Jepang. Novel ini memiliki tebal sekitar 1200 halaman. Begitu juga dengan novel Senopati Pamungkas yang menceritakan mengenai masa-masa kerajaan Majapahit karya Arswendo (2010). Novel tersebut bahkan memiliki tebal hingga 1600 halaman.

Novel biasanya juga dihubungkan dengan roman. Beberapa ahli bahkan ada yang menyamakan novel dengan roman. Sebenarnya terdapat perbedaan anatara novel dengan roman. Menurut Pujiharto (2010:8) novel adalah gambaran dari kehidupan dan perilaku yang nyata dari zaman pada saat novel itu ditulis. Romansa menggambarkan apa yang tidak pernah terjadi dan tidak mungkin terjadi. Novel bersifat realistis, sedangkan romansa bersifat epik dan puitis. Dari definisi ini kita akan bisa membedakan sebuah cerita rekaan, apakah cerita itu masuk novel atau roman.

Penulisan sebuah novel tentu tidak bisa dilepaskan dari pendekatan-pendekatan yang ada dalam dunia sastra. Menurut Abrams (1981) terdapat empat pendekatan dalam penulisan sastra. Empat pendekatan itu adalah pendekatan mimetik, pendekatan pragmatik, pendekatan ekspresif, dan pendekatan objektif. Sebelum menulis novel (yang dalam hal ini juga merupakan karya sastra) tentu kita tidak bisa terlepas dari pemilihan pendekatan-pendekatan tersebut.

\section{NOVEL SEJARAH}

Karangan berbentuk novel ternyata sudah ada sejak masa kolonial Belanda. Novel yang tercatat dan diketahui saat itu adalah novel dengan judul Rojo Pirangun karangan T.Rooda yang terbit tahun 1844. Jatha (1984: 25) membagi karya sastra modern Indonesia sebelum tahun 1928 menjadi 3 jalur. Jalur kesusastraan modern di Indonesia tersebut adalah Sastra Jawa, Sastra 
Sunda, dan Sastra Melayu. Sebagai contoh, pada tahun 1914 terbit novel berbahasa Sunda dengan judul Baharuang Ka Ku Ngarora yang dikarang oleh Daeng Kanduruhan Ardiwinata. Pada tahun 1920, diterbitkan novel berbahasa Jawa dengan judul Serat Riyanto yang dikarang oleh Raden Mas Sulardi. Jika dianalisis, maka pembagian jalur yang dilakukan oleh Jatha ini lebih didasarkan pada kedaerahan dan kebahasaan di mana novel tersebut dibuat.

Setelah tahun 1920-an tersebut, terdapat periodesasi untuk menandai ciri setiap karya sastra. Menurut Mujiyanto \& Fuadi (2014: 25-151) periodesasi penulisan sastra di Indonesia secara umum dibagi menjadi enam. Periodesasi tersebut adalah karya sastra angkatan Balai Pustaka dan Pujangga Baru, Angkatan Masa Jepang dan Angkatan '45, Angkatan Generasi Kisah, Manifes Kebudayaan Dekade 50-an dan Angkatan '66, Angkatan Sastra 1970/1980, Angkatan Sastra dekade 90 -an serta 2000-an.

Pada bagian sebelumnya telah dijelaskan bahwa novel merupakan cerita rekaan yang kebenarannya tidak bisa dipertangungjawabkan. Kebenaran dari novel adalah kebenaran yang diciptakan oleh si pengarang. Meskipun begitu, kita juga tidak bisa memungkiri bahwa dalam dunia sastra, khusunya mengenai novel terdapat bentukbentuk karya sastra yang berdasar pada fakta. Abrams (1981:61) menyebut bahwa karya fiksi yang mendasarkan ceritanya pada fakta yang terjadi sebenarnya adalah karya sastra fiksi nonfiksi (nonfiction fiction).

Karya sastra fiksi nonfiksi dapat dibagi menjadi tiga macam yaitu karya fiksi historis, karya fiksi biografis, dan karya fiksi sains. Karya fiksi historis jika yang menjadi dasar penulisan adalah fakta sejarah. Menurut Howell (2014:4), dilihat dari format dan gaya, fiksi historis ini bisa juga disebut sebagai novel sejarah. Karya fiksi biografis jika yang menjadi dasar adalah fakta biografis. Karya fiksi sains jika yang menjadi dasar adalah fakta ilmu pengetahuan. Jika dilihat dari pengertian di atas, maka kita bisa menarik kesimpulan bahwa sebenarnya ada karya sastra berupa novel yang kajiannya mengunakan dasar fakta sejarah. Sebuah karya fiksi biografis juga bisa disebut sebagai karya sastra historis karena penulisan biografi seseorang juga termasuk karya sejarah. Menurut Kuntowijoyo (2013:203) biografi juga merupakan karya sejarah. Hal ini menunjukkan kepada kita bahwa pembagian karya fiksi nonfiksi seperti yang dikatakan oleh Abrams tersebut bisa menggabungkan antara unsur historis dengan unsur sastra.

Sebagai contoh, karya fiksi nonfiksi yang bisa disebut sebagai karya sastra historis adalah karya Pramoedya (2011) dengan judul Bumi Manusia yang memiliki latar belakang historis pada masa kolonial akhir abad ke-19. Kuntowijoyo (2006: 179) bahkan mengatakan bahwa sebuah novel yang benar-benar bisa disebut sebagai sebuah novel sejarah adalah novel Bumi Manusia tersebut. Novel ini mengemukakan banyak fakta-fakta historis menganai keadaan pelik hubungan antara budaya kolonial, Indo, dan Pribumi. Contoh karya fiksi nonfiksi yang termasuk dalam biografi adalah karya Cindy Adams (2014) yang berjudul Bung Karno Penyambung Lidah Rakyat. Karya ini menceritakan mengenai kehidupan Bung Karno dengan bahasa yang mudah untuk dicerna siapapun yang membacanya. Meskipun karya ini bukan dimaksudkan oleh penulisnya sebagai karya sastra yang imajiner, namun oleh pembaca tidak jarang dinikmati sebagai sebuah karya sastra (Nurgiyantoro, 2000:5).

Novel historis, atau dalam pengembangan ini juga bisa disebut sebagai novel sejarah adalah novel yang terikat oleh faktafakta yang dikumpulkan melalui penelitian berbagai sumber. Ini berarti juga melakukan salah satu dari langkah-langkah penelitian 
sejarah yaitu heuristik. Menurut Kuntowijoyo (1994: 91) penelitian sejarah terdiri dari lima tahapan yaitu:1) pemilihan topik, 2) heuristik atau pengumpulan data, 3) kritik yang terdiri dari kritik ekstern dan intern, 4) interpretasi, dan 5) historiogafi. Heuristik merupakan pengumpulan sumber yang dilakukan untuk penulisan sejarah. Jadi, terdapat satu langkah penelitian sejarah dalam penulisan novel historis. Meskipun begitu, menurut Nurgiyantoro (2000:4) novel sejarah memberikan ruang gerak untuk fiksionalitas, misalnya dengan memberitakan pikiran dan perasaan tokoh lewat percakapan.

Pendapat lain mengenai penulisan novel sejarah disampaikan oleh Muhsin (2010:2) yang mengatakan bahwa novel dan sejarah memiliki kesamaan yaitu dalam hal imajinasi dan unsur seni. Perbedaannya adalah, kadar seni dalam sejarah amat dibatasi dan fakta harus lebih dominan sedangkan novel bersifat fiktif imajinatif yang kebenaran faktanya tidak dipersoalkan. Melihat penjelasan itu, maka peran guru dalam memilih novel sejarah yang sesuai dan berkualitas serta pendampingan dalam proses pembelajaran sangat penting agar peserta didik tidak salah dalam menafsirkan novel sejarah.

Dari penjelasan di atas kita dapat membedakan secara jelas antara novel sejarah dengan karya ilmiah sejarah. Terdapat perbedaan yang jelas antara novel sejarah dan karya ilmiah sejarah. Novel sejarah sangat kental dengan unsur subyektifitas sedangkan karya ilmiah sejarah harus menekankan lebih banyak pada obyektifitas. Novel sejarah ditulis berdasarkan proses mengimajinasikan sumber-sumber yang didapat sesuai dengan imajinasi pengarangnya masing-masing. Pengarang memiliki kebebasan untuk memuat hasil imajinasinya sendiri dalam novel sejarah. Karya ilmiah sejarah harus secara ketat melakukan verifikasi dari sumber, melakukan interpretasi yang berdasarkan pada teori-teori yang ada, dan tentu, setiap tulisannya harus bisa dipertanggungjawabkan.

Novel sejarah adalah novel yang bertema sejarah, oleh karenanya tidak bisa dilepaskan dari kebenaran sejarah. Kuntowijoyo (2006: 178) berpendapat bahwa novel sejarah yang secara sengaja menggunakan peristiwa sejarah sebagai bahan, haruslah mempunyai ikatan kepada historical truth (kebenaran sejarah). Penulisan novel sejarah tidak bisa melenceng dari realitas sejarah sekalipun unsur sastra tetap dijadikan sebagai bumbu untuk membuat cerita menjadi menarik. Menurut Lukacs (dalam Kuntowijoyo, 2006: 179) realitas sejarah yang muncul dalam novel sejarah dapat dilihat melalui adanya unsur historical authenticity (keaslian sejarah), historical faithfulness (kesetiaan sejarah), dan authentecity of local colour (kesetiaan unsur lokal). Novel sejarah yang baik hendaknya memperhatikan adanya unsur-unsur yang telah disebutkan diatas. Hal ini ditujukan agar novel sejarah sesuai dengan realitas sejarah sekaligus memiliki unsur sastra yang menarik.

Novel sejarah bisa juga dimasukkan sebagai jenis prosa fiksi sains. Menurut Cullinan (dalam Winarni, 2014:17) terdapat tiga jenis prosa yaitu prosa fiksi sains, prosa fiksi realistik, dan prosa fiksi imajinatif. Prosa fiksi sains adalah cerita fiksi yang disusun dengan penekanan pada isi yang ingin disampaikan. Isi yang disampaikan berupa ilmu pengetahuan atau bersifat faktual. Meskipun bersifat faktual, namun isi cerita tersebut disusun dalam bentuk cerita fiksi dengan cara menentukan pelaku, latar dan alur.

Penjelasan diatas sesuai dengan pendapat dari Mulyoto dalam kata pengantarnya di novel sejarah dengan judul Gajah Mada karya Langit Kresna Hariadi. Menurut Mulyoto, seorang novelis bebas 
mengolah khayalan untuk menggambarkan cerita yang ditulis, mengolah setting pada latar belakang budaya di kurun waktu tertentu, mengolah karakter tokoh-tokoh yang ditampilkan lewat dialog, tindakan, dan sikap serta mengolah konflik sesuai keinginan dan kemampuan novelis. Hal yang harus tetap diperhatikan manakala alur cerita menyangkut nama-nama, peristiwa, kronologi, dan setting memang harus sesuai dengan fakta sejarah. Agar sesuai dengan fakta sejarah, tentu saja novelis harus melakukan riset mengenai latar sejarah yang akan dia tulis. Riset ini bisa dengan menggunakan literatur yang telah ada dan bisa juga dengan wawancara secara langsung dengan tokoh sejarah atau ahli sejarah. Novelis yang menggunakan sejarah sebagai latar ceritanya sah-sah saja berimajinasi, tetapi jika mengabaikan fakta sejarah, maka akan menuai polemik, protes, dan bahkan bisa menjadi bahan tertawaan.

Dari beberapa pendapat mengenai novel sejarah di atas maka dapat ditarik kesimpulan bahwa novel bisa ditulis dengan latar belakang sejarah. Penulisan novel dengan latar belakang sejarah tidak terlepas dari pencarian sumber-sumber sejarah. Sumber-sumber sejarah tersebut diimajinasikan dalam bentuk cerita novel. Kita bisa menyebutnya sebagai novel historis atau novel sejarah. Novel sejarah meskipun tidak bisa terlepas dari sumber yang bersifat faktual, namun juga tidak bisa dilepaskan dari unsur fiksi. Sebagaimana telah diterangkan sebelumnya, fiksi merupakan cerita rekaan. Novel sejarah juga merupakan cerita rekaan, namun berdasarkan pada sumber sejarah. Kita bisa melihat kesejarahannya dari unsur-unsur yang membangun novel seperti setting waktu, tempat, dan peristiwa, serta tokoh-tokoh yang ada dalam cerita tersebut.

\section{BAHAN AJAR NOVEL SEJARAH DALAM PEMBELAJARAN SE- JARAH}

Pada bagian sebelumnya telah disampaikan beberapa permasalahan pada pembelajaran sejarah. Pembelajaran sejarah selama ini memang identik dengan pelajaran yang membosankan dan kurang menarik. Oleh karena itu, banyak praktisi pendidikan yang bergerak khususnya dalam pembelajaran sejarah berkreasi menghasilkan bahan ajar agar pembelajaran sejarah menjadi menarik. Tidak dapat dipungkiri, karya-karya tersebut berhasil menarik minat peserta didik pada pelajaran sejarah, bahkan dapat meningkatkan hasil belajar peserta didik.

Karya-karya bahan ajar yang telah hadir tentu menjadi berita gembira bagi guru sejarah. Karya-karya tersebut setidaknya mengubah stigma bahwa pelajaran sejarah merupakan pelajaran yang membosankan. Namun di sisi lain, penulis mengambil kesimpulan bahwa produk bahan ajar yang dikembangkan selama ini lebih ke arah praktis, agar peserta didik mendapatkan hasil belajar maksimal. Oleh karena itu, bahan ajar dibuat dengan jumlah kata yang seminimal mungkin. Porsi gambar, warna, bahkan animasi dibuat sebaik dan sebanyak mungkin, namun dengan pengurangan porsi pada kata-kata. Hal ini memang menarik bagi peserta didik mengingat rendahnya minat baca mereka. Peserta didik lebih tertarik dengan pembelajaran yang kontekstual daripada yang hanya tekstual.

Karya-karya bahan ajar yang menarik memang penting dalam pembelajaran sejarah, namun tentu tetap ada kekurangannya. Salah satu kekurangan yang dapat dilihat adalah berkurangnya minat baca peserta didik. Pada bagian sebelumnya telah dijelaskan bahwa pengembangan bahan ajar, baik itu berbasis animasi, video, 
audio, audio visual, dan sebagainya memiliki porsi kata yang dibuat seminimal mungkin. Peserta didik yang memang sudah memiliki minat baca yang kurang, menjadi semakin malas lagi untuk membaca. Peserta didik tentu lebih tertarik bahan ajar dengan penuh gambar dan animasi daripada membaca. Padahal pemahaman dari sebuah peristiwa tidak bisa dicapai sepenuhnya tanpa kegiatan membaca.

Fakta menyebutkan, bahwa masyarakat Indonesia memiliki minat baca yang rendah. UNESCO mencatat pada tahun 2012 indeks minat baca di Indonesia baru mencapai 0,001 (Republika, 2017). Artinya, dalam 1000 orang hanya ada satu orang yang berkegiatan membaca. Minimnya masyarakat di Indonesia yang berkegiatan membaca ini tentu bukan hanya dari minat baca yang rendah. Ketersediaan bahan bacaan juga turut mempengaruhi rendahnya kegiatan membaca.

Pada pelajaran sejarah, minat baca sangatlah penting. Pemahaman mengenai peristiwa sejarah hanya akan bisa didapat secara mendalam dengan kegiatan membaca. Oleh kerena itu, penyediaan bukubuku bacaan yang menarik pada pelajaran sejarah harus dilakukan. Karya sastra termasuk salah satu bahan bacaan yang bisa digunakan sebagai sarana untuk meningkatkan minat baca peserta didik. Menurut Khakim (2016:99) pemanfaatan karya sastra dapat digunakan untuk membangkitkan minat baca terhadap sejarah. Salah satu karya sastra yang bisa digunakan adalah novel sejarah.

Penjelasan di atas yang mendorong penulis untuk mengemukakan ide pemanfaatan bahan ajar novel sejarah dalam pembelajaran sejarah. Novel sejarah, seperti yang telah dibahas pada bagian sebelumnya, merupakan perkawinan antara sastra dan sejarah. Bahasa yang digunakan dalam novel sejarah merupakan bahasa sastra, bukan bahasa baku seperti yang ada pada tulisan ilmiah. Hal ini akan membuat peserta didik lebih tertarik untuk membaca novel sejarah daripada buku sejarah murni. Menurut Howell (2014:4) novel sejarah akan lebih mudah dimengerti daripada sejarah nonfiksi yang ilmiah karena bahasa yang digunakan lebih mudah dipahami. Kesimpulannya, dengan pemanfaatan novel sejarah, peserta didik tetap akan tertarik pada cerita di novel tersebut, meningkatkan minat baca, sekaligus pemahaman terhadap materi sejarah yang ada pada novel.

Menurut Crawford \& Zygouris-Coe (2008) peserta didik yang membaca novel sejarah akan lebih mudah memahami peristiwa sejarah karena bisa langsung terjun dalam imajinasi yang ada dalam novel sejarah. Peserta didik akan memiliki sudut pandang bahwa dirinya termasuk karakter yang ada dalam novel sejarah. Pendapat dari Crawford \& Zygouris-Coe tersebut memberikan penjelasan bahwa novel sejarah dapat memberikan perubahan yang signifikan terhadap pemahaman peserta didik. Peserta didik tidak hanya meningkatnya pemahaman tentang kejadian masa lalu, namun juga konsekuensi sosial dari peristiwa tersebut.

Penulisan novel sejarah juga bisa digunakan sebagai sarana untuk memberikan pemahaman mengenai aturan kewarganegaraan dan moral. Menurut Reynold (2006:20) novel sejarah dapat digunakan untuk meningkatkan budaya narasi dan literasi. Novel sejarah akan mengajak peserta didik untuk berimajinasi sekaligus mempelajari moral yang berkaitan dengan masalah kewarganegaraan. Proses pembangunan imajinasi dalam novel sejarah tentu tidak bisa dilepaskan dari unsur sastra. Reynold berpendapat bahwa meskipun tidak bisa dilepaskan dari unsur sastranya, fiksi sejarah juga harus memuat fakta-fakta sejarah.

Pembelajaran sejarah dengan menggunakan novel sejarah sebenarnya 
bukan merupakan hal baru. Beberapa penelitian di negara lain menunjukkan adanya pemanfaatan novel sejarah pada pembelajaran sejarah. Di Belanda, novel sejarah yang membahas mengenai perbudakan dianggap lebih dapat membantu peserta didik untuk memahami perjalanan sejarah bangsa Belanda (Parlevliet, 2016:343). Di Amerika, dengan membaca novel bertema perang dunia kedua, peserta didik mampu dibawa ke imajinasi perang dunia kedua yang hasilnya peserta didik lebih aktif dan kritis dalam debat (Slwika, 2008:61). Di Australia, novel sejarah mampu menarik dan memberi pemahaman peserta didik dalam pelajaran sejarah (Howell: 2014:10). Di Irlandia, novel sejarah mengenai kaum pengungsi yang datang di negara tersebut mampu menghadirkan perasaan empati bagi peserta didik (Bracey, dkk, 2006:103). Beberapa penjelasan tentang penelitian mengenai novel sejarah di atas memberikan gambaran bahwa sebenarnya novel sejarah dapat digunakan dalam pembelajaran sejarah.

Novel sejarah memang tidak terlepas dari unsur subyektifitas pengarang. Seperti yang telah dikemukakan pada bagian sebelumnya, novel sejarah merupakan salah satu bagian dari fiksi yang merupakan cerita rekaan. Meskipun begitu, latar sejarah dapat digunakan untuk memahami materi sejarah yang ada dalam novel tersebut. Menurut Howell (2014:10) materi sejarah dalam novel sejarah dapat dilihat dari ide karakter utama. Karakter utama dapat diambil dari karakter yang nyata ada dalam peristiwa sejarah, maupun karakter rekaan. Novel sejarah memuat unsur rekaan yang tentu saja tidak termasuk dalam materi sejarah. Guru sejarah harus bisa membimbing peserta didik untuk membedakan mana yang rekaan dan mana yang fakta. Unsur rekaan (sastra), bagaimanapun, tetap tidak bisa dilepaskan karena unsur inilah yang menarik minat baca peserta didik.
Sejarah dan fiksi memang dua hal yang berbeda, namun diantara keduanya memiliki keterikatan. Menurut Cohen (2004:317) sejarah tidak akan pernah bisa ditulis tanpa bantuan imajinasi. Unsur imajinasi ini tentu erat kaitannya dengan sebuah fiksi. Cohen juga berpendapat bahwa garis pemisah antara seorang sejarahwan dengan seorang novelis sangatlah tipis. Jika kita melihat pendapat dari Cohen di atas, maka kita dapat menarik gambaran bahwa sejarah dan fiksi memiliki keterkaitan. Perbedaan antara sejarah dan fiksi ada pada pertanggungjawaban ilmiahnya.

Menurut Groce \& Groce dengan membaca novel sejarah, peserta didik akan dapat mengembangkan kemampuan literasinya sekaligus pemahamannya terhadap peristiwa sejarah. Namun, tidak semua novel dapat diaplikasikan dalam pembelajaran sejarah. Untuk itu guru harus bisa memilih novel sejarah yang tepat sesuai dengan tujuan pembelajaran sejarah. Groce \& Groce (2005:116) membagi beberapa hal yang harus diperhatikan oleh guru dalam memilih novel sejarah yang tepat untuk diaplikasikan kepada peserta didiknya yaitu : (1) unsur romantisisme penulis, (2) sudut pandang, (3) stereotipe penulis, (4) unsur penghilangan dan penambahan peristiwa,dan (5) unsur anakronis (kesejarahannya). Dengan memperhatikan hal-hal tersebut di atas, guru dapat mengaplikasikan novel sejarah sebagai salah satu sumber belajar dalam pelajaran sejarah.

Novel sejarah, selain dapat meningkatkan pemahaman mengenai peristiwa sejarah juga dapat menjadi jembatan bagi masa lalu dan masa kini. Menurut Parlevliet (2016:343-356) novel sejarah dapat menceritakan mengenai sejarah dengan memperhatikan beberapa hal yaitu karakter dan setting. Karakter dari setiap tokoh akan menggambarkan ide dari peristiwa sejarah tersebut. Karakter utama, atau bisa disebut 
sebagai karakter protagonis utama merupakan tokoh inti yang bisa memberikan gambaran mengenai sejarah yang ditulis dalam sebuah novel sejarah. Selain itu, novel sejarah juga harus memperhatikan setting. Setting novel sejarah akan memberikan gambaran mengenai keadaan peristiwa sejarah yang ada dalam novel sejarah. Dengan begitu, novel sejarah dapat menjadi jembatan masa lalu dan masa kini sesuai dengan tujuan ditulisnya novel tersebut.

Menurut Sliwka (2008:61) fiksi seperti novel sejarah dapat membawa peritiwa sejarah menjadi lebih hidup dalam pikiran peserta didik. Novel sejarah membuat peristiwa sejarah yang bisu menjadi hidup dan berbicara. Peserta didik akan dapat mengawinkan konsep-konsep dalam pelajaran sejarah dengan peristiwa-peristiwa yang ada dalam novel sejarah. Membaca novel sejarah akan membuat peserta didik meresapi cerita tersebut dan seolah-olah ada dalam peristiwa tersebut. Peserta didik juga akan dibawa dalam kondisi emosi dari tokoh-tokoh yang ada dalam novel sejarah. Penelitian yang dilakukan oleh Sliwka menghasilkan fakta bahwa dengan membaca novel sejarah maka peserta didik akan lebih aktif dalam debat, meningkatkan minat baca, dan kemampuan menulis.

Melihat penjelasan di atas, pemanfaatan novel sejarah dalam pembelajaran sejarah di Indonesia bisa dilakukan. Hal ini melihat dari adanya novel sejarah yang sudah dicetak. Kita bisa melihat novel sejarah seperti tetralogi Bumi Manusia (Pramoedya Ananta Toer), Senopati Pamungkas (Arswendo Atmowiloto), dan Gajah Mada (Langit Kresna Hariadi) yang merupakan novel-novel dengan tema sejarah. Novel karangan sebelum kemerdekaan seperti Student Hidjo (Mas Marco) dan Max Havelaar (Eduard Douwes Dekker) juga bisa digunakan dalam pelajaran sejarah. Novel tersebut digunakan sesuai dengan materi yang akan dibahas oleh peserta didik. Sebagai contohnya, untuk menggambarkan bagaimana keadaan perkembangan surat kabar pribumi di Indonesia, guru sejarah bisa mengajak peserta didik membaca tetralogi Bumi Manusia. Pada novel tersebut juga dibahas mengenai latar belakang munculnya pergerakan nasional di nusantara. Materi dari novel tersebut dapat dihubungkan dengan materi pergerakan nasional dalam pelajaran sejarah. Guru sejarah tidak boleh melupakan bahwa sebuah novel tidak akan memberikan semua jawaban indikator materi yang dibahas, namun novel sejarah akan memperdalam pemahaman materi sejarah yang akan dibahas.

Pemanfaatan novel sejarah bagi pembelajaran sejarah di kelas juga bisa dijadikan sarana menumbuhkan nilai-nilai kebangsaan peserta didik. Novel sejarah yang dipilih tentu harus mengandung nilai-nilai kebangsaan. Sebagai contoh adalah novelnovel karya Haji Abdul Malik Karim Amrullah (Hamka). Menurut Khakim (2014:162) novel karya Hamka tersebut memiliki nilai-nilai kebangsaan dan dapat menumbuhkan rasa cinta terhadap tanah air. Novel karya Hamka ini tentu bisa dijadikan sebagai salah satu alternatif novel untuk menumbuhkan nilai kebangsaan bagi peserta didik.

Pemanfaatan novel sejarah dalam pembelajaran sejarah bukan berarti meninggalkan pemanfaatan buku teks (buku paket dan LKS). Buku teks tetap menjadi salah satu referensi utama bagi peserta didik. Menurut Kochar (2008:189) novel sejarah merupakan bacaan pelengkap. Kochar mengatakan bahwa sebagai bahan bacaan pelengkap, novel sejarah dapat memperluas wawasan sejarah bagi peserta didik. Guru bisa memberikan tugas kepada peserta didik untuk membaca sebuah novel sejarah. Pada pertemuan di kelas, guru memancing dengan beberapa kata kunci hingga 
memunculkan diskusi dalam kelas. Pemanfaatan novel sejarah juga tidak harus menghilangkan semua sumber belajar dan bahan ajar lainnya. Guru sejarah haruslah melakukan analisis kebutuhan terlebih dahulu.

Kekurangan yang bisa ditemukan dari pemanfaatan novel sejarah, selain unsur subyektifitas pengarangnya, adalah pada kurangnya jumlah novel sejarah. Novel sejarah tidak mencakup semua materi yang ada dalam pembelajaran sejarah. Oleh karena itu, guru harus selektif dalam memilih novel yang sesuai dengan kebutuhan indikator materi. Sebagai gambaran, selama ini belum ada penulis novel yang menceritakan mengenai masa praaksara di Indonesia. Tentu jika tidak ada novel yang membahas masa prakasara, maka novel tidak bisa digunakan dalam pembelajaran sejarah.

Ketika muncul pertanyaan, apakah mungkin membuat novel yang berisi cerita mengenai masa praaksara?. Tentu mungkin, bahkan sangat mungkin. Sebagai contoh, pengarang bisa saja menceritakan mengenai kisah hidup seorang arkeolog, darisitu dimasukkanlah unsur-unsur materi praaksara, maka materi praaksara akan terdapat dalam novel tersebut. Novel sejarah dengan latar belakang masa praaksara tersebut hingga kini belum ada. Oleh karena itu, perlu pengembangan lebih lanjut mengenai novel-novel sejarah agar bisa mencakup materi yang lebih luas.

Guru sejarah tidak hanya bisa menunggu seorang novelis melahirkan novel-novel sejarah yang bisa digunakan dalam pembelajaran sejarah. Guru sejarah bisa mengembangkan novel-novelnya sendiri, atau, jika terlalu susah, setidaknya mengembangkan novelet. Membuat sebuah novel memang bukan pekerjaan utama seorang guru sejarah. Seorang sastrawan sekalipun belum tentu tertarik untuk membuat sebuah novel sejarah. Namun, jika guru sejarah yang memiliki passion dalam bidang sastra, maka akan sangat menarik jika bisa mengembangkan novelnya sendiri untuk digunakan dalam pembelajaran sejarah. Hal ini mengingat jumlah novel sejarah yang masih sangat terbatas jumlahnya. Dengan begitu, novel sejarah yang dikembangkan bisa disesuaikan dengan kebutuhan peserta didik, bahkan bisa dijadikan sebagai bahan ajar dengan memberikan petunjuk penggunaan sekaligus alat evaluasinya.

Memanfaatkan sebuah novel sejarah dalam pembelajaran, bahkan mengembangkan sebuah novel sejarah dalam pembelajaran memang bukanlah hal yang mudah dilakukan. Perlu adanya analisis kebutuhan untuk menggunakan novel sejarah dalam pembelajaran sejarah. Justru inilah tantangan bagi para guru sejarah. Selama ini pengembangan bahan ajar selalu dibuat semenarik mungkin, namun tidak memperhatikan pembudayaan literasi bagi peserta didik. Dengan pemanfaatan novel sejarah dalam pembelajaran sejarah, selain menarik, juga dapat meningkatkan minat baca serta pemahaman peserta didik terhadap peristiwa sejarah.

\section{CATATAN PENUTUP}

Pemanfaatan dan pengembangan bahan ajar sejarah yang selama ini dilakukan ternyata melupakan satu hal penting, yaitu membudayakan minat baca peserta didik. Masalah utama yang dihadapi dalam pembelajaran sejarah adalah bagaimana membuat peserta didik memiliki pemahaman sejarah yang luas dengan bahan ajar yang menarik. Pemahaman sejarah tidak akan dimiliki peserta didik tanpa banyak membaca. Melihat permasalahan ini, novel sejarah bisa digunakan sebagai salah satu alternatif bacaan bagi peserta didik. Pemilihan novel sejarah ini didasarkan pada kenyataan bahwa bahasa yang digunakan dalam novel 
lebih menarik daripada bahasa yang ada dalam buku paket dan LKS. Peserta didik akan dapat mengembangkan budaya literasi sekaligus mendapatkan pemahaman sejarah dengan membaca novel sejarah. Novel sejarah juga akan mengembangkan daya imajinasi peserta didik. Pemanfaatan novel sejarah dalam pembelajaran sejarah ini bukan berarti meniadakan bahan ajar lainnya. Penggunaan buku paket dan LKS sebagai buku teks utama juga tetap diperlukan untuk memberikan dasar konsep materi sejarah yang akan dibahas. Penggunaan novel sejarah harus disesuaikan dengan kebutuhan peserta didik.

Terdapat beberapa kekurangan yang juga harus diperhatikan dalam pemanfaatan novel sejarah dalam pembelajaran sejarah. Kekurangan yang pertama adalah novel sejarah tidak akan pernah terlepas dari unsur rekaan atau imajinasi pengarangnya. Kekurangan kedua adalah jumlah novel sejarah yang bisa digunakan sesuai dengan materi sejarah sesuai dengan kurikulum masih minim jumlahnya. Dari kekurangan yang telah disebutkan, tetap ada peluang bagi pemanfaatan novel sejarah dalam pembelajaran sejarah. Fakta yang didapat penulis adalah bahwa dalam pembelajaran sejarah di negara maju seperti Belanda, Australia, dan Amerika telah memanfaatkan novel sejarah sebagai salah satu bahan ajar. Dari proses membaca novel sejarah, peserta didik akan memiliki daya kritis dan guru bisa menggunakan metode debat dalam kelas. Tentu, peran guru sebagai fasilitator peserta didik tetap diperlukan dalam proses pembelajaran seperti ini. Dengan membaca novel sejarah, diharapkan peserta didik akan lebih mudah memahami materi sejarah sekaligus mengembangkan imajinasinya dalam sebuah karya sastra.

\section{DAFTAR RUJUKAN}

Abrams, M.H. 1981. A Glossary of Literary Terms. New York: Holt, Renehart and Winston.

Adams, C. 2014. Bung Karno Penyambung Lidah Rakyat. Jakarta: Yayasan Bung Karno.

Agung, L dan Wahyuni, S. 2013. Perencanaan Pembelajaran Sejarah. Yogyakarta:Penerbit Ombak.

Aman. 2011. Model Evaluasi Pembelajaran Sejarah. Yogyakarta. Ombak.

Aminuddin. 2004. Pengantar Apresiasi Sastra. Bandung: Sinar Baru Algesindo.

Ariffiantono, S. 2011.Pengembangan Pembelajaran Berbasis E-Learning Dengan Aplikasi Moodle Sejarah Eropa SMA Kelas XI di SMAN 10 Malang. Tesis tidak diterbitkan. Malang. Universitas Negeri Malang.

Atmowiloto, A. 2010. Senopati Pamungkas. Jakarta: Gramedia Pustaka Utama.

Bracey, P., Grove-Humpries, A. dan Jackson, D.. 2006. Refugees and Evacuees: Enhancing Historical Understanding Through Irish Historical Fiction with Key Stage 2 and Early Key Stage 3 pupils. Education 313. 34. no. 2: 103-112.

Garvey, B dan Krug, M. 2015. ModelModel Pembelajaran Sejarah di Sekolah Menengah. Yogyakarta: Ombak.

Cohen, S. 2004. An Essay in The Aid of Writing History: Fictions of Historiography. Studies in Philosophy and Education. 23: 317-332. 
Crawford, P. \& V. Zygouris-Coe. 2008. Those Were the Days: Learning about History Through Literature. Children Education. 84. no. 4: 197.

Departemen Pendidikan Nasional. 1995. Kamus Besar Bahasa Indonesia. Jakarta: Balai Pustaka.

Groce, E. \& Groce, R. 2005. Authenticating Historical Fiction: Rationale $\&$ Process. Education Research and Perspectives. 32 (1): 99-119.

Hariadi, L.K. 2013. Gajah Mada: Tahta dan Angkara. Solo: Tiga Serangkai.

Hill, C.P. 1956. Saran-Saran tentang Mengadjarkan Sedjarah. Jakarta: Perpustakaan Perguruan Kem. P.P. dan K.

Howell, J. 2014. Popularising History: Reigniting Pre-Service Teacher and Student Interest in History via Historical Fiction. Australian Journal of Teacher Education. 39(12): 1-12.

Jatha, P. W. 1984. Pendakian Narasi. Nusa Indah: Flores.

Khakim, N. L. 2012. Nilai Kebangsaan Dakam Karya Sastra Hamka. Jurnal Sejarah dan Budaya. 8(2): 152-164

2014. Telaah Penulisan Karya Sastra Sebagai Refleksi Sumber Pembelajaran Sejarah. Jurnal Sejarah dan Budaya. 10(1): 94-100

Kochar, S.K. 2008. Pembelajaran Sejarah: Teaching of History. Grasindo: Jakarta.

Kuntowijoyo. 1994. Metodologi Sejarah. Yogyakarta: Jurusan Sejarah Fakultas Sastra Universitas Gajah Mada.
Kuntowijoyo. 2006. Budaya dan Masyarakat. Yogyakarta: PT Tiara Wacana 2008. Metodologi Sejarah. Yogyakarta: PT. Tiara Wacana. . 2013. Metodologi Sejarah. Yogykarta: PT. Tiara Wacana.

Lestari, I. 2013. Pengembangan Bahan Ajar Berbasis Kompetensi. Jakarta: Academia.

Muhsin Z., Mumuh. 2010. Novel dan Sejarah. Disampaikan dalam bedah novel sejarah Remy Sylado. 2010. Namaku Mata Hari. Jakarta. Gramedia, Himpunan Mahasiswa Sejarah Universitas Padjajaran, Bandung, 13 Desember.

Mujiyanto, Y \& Fuady, A. 2014. Kitab Sejarah Sastra Indonesia. Yogyakarta: Ombak.

Notosutanto, N. 1979. Sejarah Demi Masa Kini. Jakarta: UI-Press.

Nurgiyantoro, B. 2000. Teori Pengkajian Fiksi. Yogyakarta: Gajah Mada University Press.

Nurhayati, E. S. 2016. Pengembangan Multimedia Interaktif Materi IPS Berbasis Inquiri Kelas V Tema Sejarah Peradaban Indonesia. Hartono, Feby. 2016. Pengembangan Bahan Ajar Sejarah Tentang Biografi Raden Inten II Untuk Meningkatkan Kemampuan Berfikir Kritis Siswa SMA Negeri 2 Sekampung Tahun 20152016. Tesis tidak diterbitkan. Malang. Universitas Negeri Malang.

Parlevliet, S. 2016. Is That Us? Dealing With The 'Black' Pages of History in Historical Fiction for Children (1996-2010). 
Children's Literature in Education. 47: 343-356.

Pujiharto. 2012. Pengantar Teori Fiksi.

Yogyakarta: Ombak.

Republika. 2017. In Picture : Minat Baca di

Indonesia Masih Rendah, (Online), (http://m.repub-

lika.co.id/berita/inpic-

ture/jabotabek-inpic-

ture/17/03/02/om8k8g283-

minat-baca-di-indonesia-

masih-rendah , diakses 10

April 2017).

Reynolds, R. 2006. The Values of Historical

Fiction: avenue to globab citizenship. Social Educa-

tor. 24. no. 1: 14-25.

Romadloni, S. 2016. Pengembangan Bahan Ajar Digital Sejarah Nasional Indonesia Berbasis Kakawin Negarakretagama Untuk Meningkatkan Kemampuan Eksplanasi Sejarah Mahasiswa Program Studi Sejarah FKIP Universitas Jember. Tesis tidak diterbitkan. Surakarta. Universitas Sebelas Maret Surakarta.

Sliwka, C. 2008. Connecting to History Through Historical Fiction. Language Arts Journal of Michigan. 23(11): 61-66.

Toer, P.A. . 2011. Bumi Manusia. Jakarta: Lentera Dipantara.

Widja, I G. 2012. Menuju Wajah Baru Pendidikan Sejarah. Yogyakarta: Graha Ilmu.

Winarni, R. 2014. Kajian Sasta Anak. Yogyakarta: Graha Ilmu.

Yoshikawa, E. 2012. Musashi. Jakarta: Gramedia Pustaka Utama. 